\title{
PENGGUNAAN MODEL PEMBELAJARAN VISUALIZATION AUDITORY KINESTETIC (VAK) UNTUK MENINGKATKAN HASIL BELAJAR SISWA PADA PEMBELAJARAN TEMATIK DI KELAS V-A UPT. SD NEGERI 01 LIMO KAUM
}

\author{
FERAWATI
}

ferawati01@gmail.com

\begin{abstract}
A structural learning model that can use several methods, techniques and learning strategies at once, the learning model must be student-centered so that learning objectives can be achieved. However, the reality is that learning in the classroom tends to be centered on the teacher (teacher centered learning) so that students are more dominant passive than active, this has an impact on student learning outcomes to be low. The research questions in this study are how the teacher's activities, student activities, and how to improve student learning outcomes in class $V$ A UPT. SD Negeri 01 Limo Kaum. This research is a field research using quantitative and qualitative methods. Data were collected through observation and tests, then the data were analyzed using a percentage formula. The results of the study found that the activity of the teacher in cycle I reached $71.88 \%$, in cycle II reached $76.56 \%$ and cycle III reached $95.31 \%$. Student activity in cycle I reached $70.31 \%$, cycle II reached $75 \%$, and in cycle III 87.5\%. The learning outcomes of students who completed the first cycle reached $68.57 \%$, the second cycle reached $82.86 \%$, and the third cycle reached 91.43\%. Thematic learning is getting better with the Visualization Auditory Kinesthetic (VAK) model to improve student learning outcomes because this learning model combines the three learning modalities to make students feel comfortable and the learning perceived by students feels more meaningful.
\end{abstract}

Keywords: VAK Model, Learning Outcomes, Thematic.

Abstrak: Model pembelajaran struktur yang dapat menggunakan beberapa metode, teknik dan strategi pembelajaran sekaligus, model pembelajaran harus berpusat paa siswa agar tujuan pembelajaran dapat tercapai. Akan tetapi, kenyataannya pembelajaran di kelas cenderung berpusat pada guru (teacher centered learning) sehingga lebih dominan siswa pasif daripada aktif, hal tersebut berdampak terhadap hasil belajar siswa menjadi rendah. Pertanyaan penelitian dalam penelitian ini bagaimanakah aktivitas guru, aktivitas siswa, serta bagaimana peningkatan hasil belajar siswa di kelas V-A UPT. SD Negeri 01 Limo Kaum. Penelitian ini merupakan penelitian lapangan dengan menggunakan metode kuantitatif dan kualitatif. Data dikumpulkan melalui observasi dan tes, kemudian data tersebut dianalisis menggunakan rumus persentase. Hasil penelitian ditemukan bahwa aktivitas guru siklus I mencapai 71,88\%, pada siklus II mencapai 76,56\% dan siklus III mencapai 95,31\% Aktivitas siswa siklus I mencapai 70,31\%, siklus II mencapai 75\%, dan pada siklus III 87,5\%. Hasil belajar siswa yang tuntas siklus I mencapai $68,57 \%$, siklus II mencapai $82,86 \%$, dan siklus III mencapai 91,43\%. Pembelajaran tematik semakin baik dengan adanya model Visualization Auditory Kinestetic (VAK) untuk meningkatkan hasil belajar siswa karena model pembelajaran ini mengombinasikan ketiga modalitas belajar untuk menjadikan peserta didik merasa nyaman dan pembelajaran yang dirasakan siswa terasa lebih bermakna.

Kata Kunci: Model VAK, Hasil Belajar, Tematik. 


\section{A. Pendahuluan}

Pendidikan adalah suatu proses mendidik siswa dari tidak tahu menjadi tahu, dan membimbing siswa dari tidak tahu menjadi tahu, dan membimbing siswa dari perilaku salah menjadi benar. Menurut Darmaningtyas pendidikan adalah usaha sadar dan sistematis untuk mencapai taraf hidup atau kemajuan yang lebih baik. Pendidikan seharusnya mampu menghasilkan sumber daya manusia yang memiliki kemampuan yang utuh, yakni kompetensi sikap, kompetensi pengetahuan, dan kompetensi keterampilan yang terintegrasi. Kompetensi tersebut terdapat pada kurikulum 2013 yang memperkuat proses pembelajaran dan penilaian autentik untuk mencapai kompetensi sikap, pengetahuan, dan keterampilan. Salah satu prinsip kurikulum 2013 yaitu pembelajarannya berpusat pada siswa atau student centered learning yakni menuntut partisipasi yang tinggi dari peserta didik, karena selama kegiatan pembelajaran berlangsung peserta didik menjadi pusat perhatian. Student centered learning berlandaskan pada teori konstruksivistik yang berasal dari teori belajar menurut Piaget, Jhon Dewei, dan Burner. Student centered learning dalam konteks scientific approach yang menekankan proses pembelajaran pada perubahan tingkah laku peserta didik itu sendiri dan mengalami langsung bagaimana membentuk konsep belajar dan memahami.

Berdasarkan observasi proses pembelajaran tematik di kelas V-A UPT. SD Negeri 01 Limo Kaum pada materi panas dan perpindahannya, yang diamati penulis, menemukan bahwa pembelajaran masih cenderung berpusat pada guru (teacher centered learning) disebabkan metode yang diterapkan ketika pembelajaran berlangsung berupa metode ceramah, tanya jawab, dan penugasan individual sehingga pembelajaran terasa kaku dimana hanya siswa yang duduk di barisan pertama yang aktif, sedangkan siswa yang duduk di barisan kedua dan seterusnya tergolong pasif hal tersebut dapat dilihat ketika guru melontarkan pertanyaan kepada siswa, dimana beberapa siswa tidak mengetahui jawabannya karena ketika guru menjelaskan materi siswa sibuk dengan aktivitas masing-masing sehingga fokus siswa untuk belajar kurang. Hasil wawancara dengan guru tersebut menunjukkan bahwa media yang diperlukan dalam pembelajaran jarang digunakan, khususnya pada materi materi panas dan perpindahannya, yang seharusnya memerlukan media gambar. Berdasarkan pemaparan masalah di atas, model pembelajaran yang relevan adalah model pembelajaran Visualization Auditory Kinestetic (VAK), karena model pembelajaran ini dapat mendukung siswa dalam memahami materi pembelajaran disebabkan ketiga modalitas belajar sudah terangkum dalam satu proses pembelajaran sehingga menjadikan siswa merasa nyaman ketika pembelajaran berlangsung.

Berdasarkan hasil penelitian di atas, peneliti tertarik untuk membuat PTK yang berjudul "Penggunaan Model Pembelajaran Visualization Auditory Kinestetic (VAK) untuk Meningkatkan Hasil Belajar Siswa pada Pembelajaran Tematik di Kelas V-A UPT. SD Negeri 01 Limo Kaum”.

Berdasarkan pemaparan latar belakang masalah di atas maka yang menjadi rumusan masalah adalah: 1) Bagaimanakah aktivitas guru dalam pembelajaran tematik dengan model Visualization Auditory Kinestetic (VAK) di kelas V-A UPT. SD Negeri 01 Limo Kaum? 2) Bagaimanakah aktivitas siswa dalam pembelajaran tematik dengan model Visualization Auditory Kinestetic (VAK) di kelas V-A UPT. SD Negeri 01 Limo Kaum? 3) Bagaimanakah peningkatan hasil belajar siswa pada pembelajaran pembelajaran tematik dengan model Visualization Auditory Kinestetic 
(VAK) di kelas V-A UPT. SD Negeri 01 Limo Kaum? Tujuan yang ingin dicapai dalam penelitian ini adalah: 1) Untuk mengetahui aktivitas guru dalam pembelajaran tematik dengan model Visualization Auditory Kinestetic (VAK) di kelas V-A UPT. SD Negeri 01 Limo Kaum; 2) Untuk mengetahui aktivitas siswa dalam pembelajaran tematik dengan model Visualization Auditory Kinestetic (VAK) di kelas V-A UPT. SD Negeri 01 Limo Kaum; dan 3) Untuk meningkatkan hasil belajar siswa pada pembelajaran tematik dengan menggunakan model Visualization Auditory Kinestetic (VAK) di kelas V-A UPT. SD Negeri 01 Limo Kaum.

\section{B. Metodologi Penelitian}

Jenis penelitian yang digunakan dalam penelitian ini adalah Penelitian Tindakan Kelas (PTK) atau Classroom Action Research (CAR) adalah proses berpikir sempurna. Pelaksanaannya harus dirancang sedemikian rupa agar hasilnya berguna untuk meningkatkan kualitas proses pembelajaran. (Wina Sanjaya 2012: 63) Dengan demikian, PTK disebut juga penelitian untuk memperbaiki kesalahankesalahan dalam proses pembelajaran, sehingga mutu pembelajaran dan hasil belajar siswa mengalami peningkatan. PTK merupakan penelitian tindakan yang diaplikasikan di dalam kelas ketika pembelajaran berlangsung (Candra Wijaya dan Syahrum, 2013: 39) Tujuan PTK untuk memperbaiki dan meningkatkan mutu pembelajaran. PTK berfokus proses pembelajaran yang terjadi di dalam kelas. Melalui PTK, guru dapat meningkatkan kinerjanya secara terus-menerus, dengan cara melakukan refleksi diri (self reflection). Model PTK yang digunakan pada penelitian ini adalah model Kemmis dan Mc Taggart berupa model siklus yaitu model yang lebih menonjolkan tahaptahap yang harus dilaksanakan oleh setiap peneliti dalam setiap kali putaran.

\section{Hasil dan Pembahasan Deskripsi Kondisi Awal/Pra Siklus}

Penelitian ini dilaksanakan karena berbagai faktor, salah satu diantaranya adalah rendahnya nilai mata pembelajaran Tematik Tema Panas dan Perpindahannya yang diperoleh siswa kelas V-A UPT SD Negeri 01 Limo Kaum Kecamatan Lima Kaum Kabupaten Tanah Datar, pada nilai ulangan pembelajaran dengan menggunakan strategi pembelajaran konvensional. Adapun hasil belajar siswa sebagai gambaran awal adalah sebagai berikut: 
Tabel Pencapaian Hasil Belajar Tematik Siswa pada Pra Siklus

\begin{tabular}{|c|c|c|c|c|c|}
\hline No & Nama Pererta Didik & KKM & Nilai & Tuntas. & Belum Tuntas. \\
\hline 1 & Adnan Pikri Arrahonan & 80 & 40 & & $\checkmark$ \\
\hline 2 & Ahmad Faisal & 80 & 80 & $\checkmark$ & \\
\hline 3 & Amira Puti Maharani & 80 & 80 & $\checkmark$ & \\
\hline 4 & Angelita Folia Annisa & 80 & 60 & & $\sqrt{ }$ \\
\hline 5 & Anil Okta Fumal. & 80 & 20 & & $\checkmark$ \\
\hline 6 & Aqilah Fatixah Aalaka & 80 & 80 & $\checkmark$ & \\
\hline 7 & Aulia Fitri & 80 & 40 & & $\checkmark$ \\
\hline 8 & Faswatab. In Aroila. & 80 & 80 & $\checkmark$ & \\
\hline 9 & Haxkal Azmi & 80 & 60 & & $\checkmark$ \\
\hline 10 & Tbrahim Arrasxid Idri & 80 & 80 & $\checkmark$ & \\
\hline 11 & Kovin Trio Putra & 80 & 40 & & $\checkmark$ \\
\hline 12 & Kirana Zazkia. PuksiayM & 80 & 80 & $\sqrt{ }$ & \\
\hline 13 & Miftahul Rahmi & 80 & 00 & & $\checkmark$ \\
\hline 14 & Muhammad Pajri & 80 & 80 & $\checkmark$ & \\
\hline 15 & Muhamamad Farel Alsagate. & 80 & 100 & $\sqrt{ }$ & \\
\hline 16 & Muharmmad Fathis. & 80 & 80 & $\checkmark$ & \\
\hline 17 & Muhammad Tkhsian & 80 & 40 & & $\sqrt{ }$ \\
\hline 18 & Muhammad Rizki & 80 & 40 & & $\checkmark$ \\
\hline 19 & Muhammed Faiz Hafidzi & 80 & 80 & $\checkmark$ & \\
\hline 20 & Nadia Ramadhani & 80 & 80 & $\checkmark$ & \\
\hline 21 & Nadita Nur Azizah & 80 & 80 & $\checkmark$ & \\
\hline 22 & Nazwa L-ailatus. Wabda. & 80 & 40 & & $\checkmark$ \\
\hline 23 & Okta Dava Saputra & 80 & $\infty 0$ & & $\checkmark$ \\
\hline 24 & Fatbal Ma:Arui & 80 & so & $\checkmark$ & \\
\hline 25 & Rakba Alvaro Panendra. & 80 & 60 & & $\checkmark$ \\
\hline 26 & Redyme Desxica & 80 & 80 & $\checkmark$ & \\
\hline 27 & Rehan Setiawan & 80 & 20 & & $\checkmark$ \\
\hline 28 & Birarul Aisyab. & 80 & 40 & & $\sqrt{ }$ \\
\hline 29 & Rizky Alrachab & 80 & 80 & $\checkmark$ & \\
\hline 30 & Steyj Padilla & 80 & 80 & $\checkmark$ & \\
\hline 31 & Syigriel Arafat Eursagoiy. & 80 & 60 & & $\checkmark$ \\
\hline 32 & USwatur RUAL & so & 20 & & $\checkmark$ \\
\hline 33 & Yaliza Roga & 80 & 40 & & $\checkmark$ \\
\hline & Dwi Msylantian Saputri & Ro & Ro & $\checkmark$ & \\
\hline \multicolumn{3}{|c|}{ Jamlah } & 2120 & 17 & 17 \\
\hline \multirow{2}{*}{\multicolumn{4}{|c|}{ 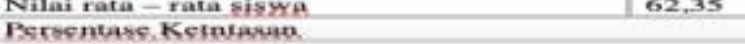 }} & & \\
\hline & & & & $50 \%$ & 5006 \\
\hline
\end{tabular}

Berdasarkan tabel di atas, rata-rata kelas yang diperoleh adalah 62,25. Siswa yang mencapai KKM ( 80 ) sejumlah 17 siswa atau sebesar 50\% sedangkan siswa yang nilainya belum mencapai KKM sejumlah 17 siswa atau sebesar 50\%. Apabila pencapaian hasil belajar siswa pada kondisi awal disajikan dalam bentuk diagram tabung sebagai berikut:

\section{Gambar Pencapaian Hasil Belajar Siswa pada Kondisi Pra Siklus}

Fakta yang ada menunjukkan masih rendahnya tingkat keberhasilan belajar siswa pada mata pelajaran Tematik Tema Panas dan Perpindahannya. Rendahnya hasil belajar siswa yang terindikasi disebabkan oleh strategi mengejar target pencapaian kurikulum dan materi yang ada di buku sehingga guru memilih proses belajar mengajar yang cepat. Kesempatan siswa untuk menemukan konsep sendiri jarang diberikan ke siswa. Siswa tidak diberi kesempatan untuk belajar aktif, kreatif, dan menyenangkan karena siswa hanya sebagai objek belajar yang pasif. Berdasarkan beberapa tinjauan di atas, peneliti mencoba untuk memperbaiki kondisi semacam itu dengan Menggunakan Model Pembelajaran Visualization Auditory Kinestetic (VAK).

\section{Deskripsi Siklus I}

Siklus ini dilaksanakan melalui empat tahap yaitu perencanaan, pelaksanaan, observasi dann refleksi. Guru memberikan soal evaluasi untuk mengetahui pemahaman siswa setelah digunakan model Visualization Auditory Kinestetic (VAK) yang diikuti 34 siswa, dengan kriteria ketuntasan minimal 80. Hasil tes belajar pada siklus 1 pada tema 6 subtema 2 pembelajaran 2, dapat dilihat pada tabel di bawah ini: 
Tabel Pencapaian Hasil Belajar Tematik Siswa pada Siklus I

\begin{tabular}{|c|c|c|c|c|c|}
\hline No & Nama Peserta Didik & KKM & Nilai & Tuntas & Belum Tuntas \\
\hline $\mathbf{1}$ & Adnan Fikri Arrahman & 80 & 60 & & $\sqrt{ }$ \\
\hline 2 & Ahmad Faisal & 80 & 80 & $\sqrt{ }$ & \\
\hline 3 & Amira Puti Maharani & 80 & 80 & $\sqrt{ }$ & \\
\hline 4 & Angelita Felia Annisa & 80 & 80 & $\sqrt{ }$ & \\
\hline 5 & Aqil Okta Fitma & 80 & 40 & & $\sqrt{ }$ \\
\hline 6 & Aqilah Fatixah Adzka & 80 & 80 & $\sqrt{ }$ & \\
\hline 7 & Aulia Fitri & 80 & 60 & & $\sqrt{ }$ \\
\hline 8 & Pauziah In Amila & 80 & 80 & $\checkmark$ & \\
\hline 9 & Haykal Azmi & 80 & 80 & $\sqrt{ }$ & \\
\hline 10 & Jbrahim Arrasyid Idri & 80 & 80 & $\sqrt{ }$ & \\
\hline 11 & Kevin Trio Putra & 80 & 60 & & $\sqrt{ }$ \\
\hline 12 & Kirana Zazkia Putriayu & 80 & 80 & $\checkmark$ & \\
\hline 13 & Miftahul Rahmi & 80 & so & $\checkmark$ & \\
\hline 14 & Muhammad Fajri & 80 & 80 & $\sqrt{ }$ & \\
\hline 15 & Muhammad Farel Alrazag & 80 & 100 & $\sqrt{ }$ & \\
\hline 16 & Muhammad Fathir. & 80 & 80 & $\sqrt{ }$ & \\
\hline 17 & Muhammad Ikhsan & 80 & 60 & & $\sqrt{ }$ \\
\hline 18 & Muhammad Rizki & 80 & 60 & & $\sqrt{ }$ \\
\hline 19 & Muhammed Faiz Hafidzi & 80 & 80 & $\sqrt{ }$ & \\
\hline 20 & Nadia Ramadhani & 80 & 80 & $\sqrt{ }$ & \\
\hline 21 & Nadifa Nur Azizah & 80 & 100 & $\sqrt{ }$ & \\
\hline 22 & Nazwa I ailatul Wahda & 80 & 60 & & $\sqrt{ }$ \\
\hline 23 & Okta Dava Saputra & 80 & 80 & $\sqrt{ }$ & \\
\hline 24 & Pathul Ma'Arii & 80 & 80 & $\sqrt{ }$ & \\
\hline 25 & Rakha Alvaro Danendra & 80 & 80 & $\sqrt{ }$ & \\
\hline 26 & Redyna Desvita & 80 & 80 & $\sqrt{ }$ & \\
\hline 27 & Rehan Setiawan & 80 & 40 & & $\sqrt{ }$ \\
\hline 28 & Rifatul Aisyah & 80 & 60 & & $\sqrt{ }$ \\
\hline 29 & Rizky Alfathah & 80 & 80 & $\sqrt{ }$ & \\
\hline 30 & Stevi Fadilla & 80 & 80 & $\checkmark$ & \\
\hline 31 & Syigqiel Arafat Furqaniy. & 80 & 80 & $\sqrt{ }$ & \\
\hline 32 & Uswatur Rijal & 80 & 40 & & $\sqrt{ }$ \\
\hline 33 & Valiza Roofi & 80 & 60 & & $\sqrt{ }$ \\
\hline 34 & Dwi Meylantia Saputri & 80 & 80 & $\sqrt{ }$ & \\
\hline \multicolumn{3}{|c|}{ Jumlah } & 2480 & 23 & 11 \\
\hline \multirow{2}{*}{\multicolumn{4}{|c|}{$\begin{array}{l}\text { Nilai rata - rata siswa } \\
\text { Persentase Ketuptasan }\end{array}$}} & & \\
\hline & & & & $67.65 \%$ & $32,35 \%$ \\
\hline
\end{tabular}

Berdasarkan daftar nilai hasil tes belajar siswa pada tabel di atas rata-rata kelas yang diperoleh adalah 72,94 diketahui bahwa siswa yang tuntas belajar berjumlah 23 orang dengan persentase 67,65\% dan siswa yang tidak tuntas belajar berjumlah 11 orang dengan persentase $32,35 \%$. Berkaitan dengan KKM yang ditetapkan di kelas VA UPT SD Negeri 01 Limo Kaum Kecamatan Lima Kaum Kabupaten Tanah Datar bahwa seorang siswa dikatakan tuntas belajar apabila memiliki nilai kriteria ketuntasan minimal 80 dan dikatakan tuntas secara klasikal apabila mencapai $85 \%$ siswa tuntas belajarnya. Dengan demikian, dapat disimpulkan bahwa ketuntasan belajar siswa siklus I belum tuntas. Pencapaian hasil belajar siswa pada siklus I disajikan dalam bentuk diagram tabung sebagai berikut:

\section{Gambar Pencapaian Hasil Belajar Siswa pada Siklus I}

Berdasarkan tabel hasil belajar siswa belum tuntas sebanyak 12 orang, hal tersebut dikarena terdapat beberapa kendala yang mereka hadapi yaitu, siswa kurang berani untuk bertanya hal-hal yang belum dipahami, masih kurang paham terhadap tema 6 subtema 2 pembelajaran 2 yang dipelajari, rendahnya siswa yang mampu menyimpulkan pembelajaran tersebut. dengan demikian, untuk siklus I hasil belajar siswa belum mencapai ketuntasan secara klasikal karena siswa belum paham materi tersebut. Jadi, peneliti harus melakukan siklus II untuk merevisi kekurangan pada siklus I.

\section{Deskripsi Siklus II}

Siklus II terdiri dari tahap perencanaan, tahap implementasi, tahap observasi dan tahap refleksi. Guru memberikan soal evaluasi (post test) untuk mengetahui pemahaman siswa setelah digunakan model Visualization Auditory Kinestetic (VAK) 
yang diikuti 34 siswa, dengan kriteria ketuntasan minimal 80. Hasil tes belajar pada siklus 1 pada tema 6 subtema 2 pembelajaran 2, dapat dilihat pada tabel di bawah ini:

\section{Tabel Pencapaian Hasil Belajar Tematik Siswa pada Siklus II}

\begin{tabular}{|c|c|c|c|c|c|}
\hline No & Nama Peserta Didik & KKM & Nilai & Thantas. & Belum Tuntas. \\
\hline 1 & Adnan Fikri Arrahoman & 80 & 80 & $\sqrt{ }$ & \\
\hline 2 & Ahmad Faisal & 80 & 80 & $\sqrt{ }$ & \\
\hline 3 & Amira Puti Maharani & so & so & $\sqrt{ }$ & \\
\hline 4 & Angelita Felia Annisa & 80 & 80 & $\sqrt{ }$ & \\
\hline 5 & Agil Okta Fitma. & 80 & 40 & & $\sqrt{ }$ \\
\hline 6 & Aqilab. Fatixah Adzka & so & so & $\sqrt{ }$ & \\
\hline 7 & Aulia Fitri & 80 & 60 & & $\checkmark$ \\
\hline 8 & Fauziah In Arrila & 80 & 80 & $\sqrt{ }$ & \\
\hline 9 & Haxkal Azmi & so & 80 & $\checkmark$ & \\
\hline 10 & Ibrahim Arrasyid. Idrj & 80 & 80 & $\sqrt{ }$ & \\
\hline 11 & Kevin Trio Putra & 80 & so & $\sqrt{ }$ & \\
\hline 12 & Kirana Zaykia Putxiaym & so & 80 & $\sqrt{ }$ & \\
\hline 13 & Miftahul Rahmi & 80 & 80 & $\sqrt{ }$ & \\
\hline 14 & Muhammad Fajri & 80 & 80 & $\sqrt{ }$ & \\
\hline 15 & Muhammad Farel Alrazaq. & 80 & 100 & $\sqrt{ }$ & \\
\hline 16 & Muhammad Fatbix. & so & 80 & $\sqrt{ }$ & \\
\hline 17 & Muhammad Ikhsan & 80 & 60 & & $\checkmark$ \\
\hline 18 & Muhammad Rizki & 80 & 80 & $\sqrt{ }$ & \\
\hline 19 & Muhammed Faiz Hafidzi & so & 80 & $\sqrt{ }$ & \\
\hline 20 & Nadia Ramadhani & 80 & 80 & $\sqrt{ }$ & \\
\hline 21 & Nadifa Nur Azizah & 80 & 100 & $\checkmark$ & \\
\hline 22 & Nazwa J-ailasul Wabga & 80 & 60 & & $\sqrt{ }$ \\
\hline 23 & Okta Dava Sapatra & so & 80 & $\sqrt{ }$ & \\
\hline 24 & Pathul Ma'Arii & 80 & 80 & $\checkmark$ & \\
\hline 25 & Rakha Alvaro Danendra & 80 & 80 & $\sqrt{ }$ & \\
\hline 26 & Redyna Resxica & 80 & 80 & $\sqrt{ }$ & \\
\hline 27 & Rehan Setiawan & so & 40 & & $\sqrt{ }$ \\
\hline 28 & Rifatul Aisyab & 80 & 80 & $\sqrt{ }$ & \\
\hline 29 & Rizky Alfathah & 80 & 80 & $\sqrt{ }$ & \\
\hline 30 & Steyi Fadilla & 80 & 80 & $\checkmark$ & \\
\hline 31 & Syiggiel Arafat Furganiy. & 80 & 80 & $\sqrt{ }$ & \\
\hline 32 & Uswatur Rival & 80 & 60 & & $\checkmark$ \\
\hline 33 & Valiza Rooti & 80 & 60 & & $\sqrt{ }$ \\
\hline 34 & Dwi Meylantia Saputri & 80 & 80 & $\checkmark$ & \\
\hline \multicolumn{3}{|c|}{ Jumlah } & 2580 & 27 & 7 \\
\hline \multicolumn{3}{|c|}{ Nilai rata - rata sisyya } & 75,88 & & \\
\hline
\end{tabular}

Berdasarkan daftar nilai hasil tes belajar siswa pada tabel di atas rata-rata kelas yang diperoleh adalah 75,88 diketahui bahwa siswa yang tuntas belajar berjumlah 27 orang dengan persentase $79,41 \%$ dan siswa yang tidak tuntas belajar berjumlah 7 orang dengan persentase 20,59\% Berkaitan dengan KKM yang ditetapkan di kelas V-A UPT SD Negeri 01 Limo Kaum Kecamatan Lima Kaum Kabupaten Tanah Datar bahwa seorang siswa dikatakan tuntas belajar apabila memiliki nilai kriteria ketuntasan minimal 80 dan dikatakan tuntas secara klasikal apabila mencapai $85 \%$ siswa tuntas belajarnya. Dengan demikian, dapat disimpulkan bahwa ketuntasan belajar siswa siklus I belum tuntas. Pencapaian hasil belajar siswa pada siklus II disajikan dalam bentuk diagram tabung sebagai berikut:

\section{Gambar Pencapaian Hasil Belajar Siswa pada Siklus II}

Berdasarkan hasil belajar siswa belum tuntas sebanyak 6 orang, hal tersebut dikarena terdapat beberapa kendala yang mereka hadapi yaitu, masih ada siswa kurang berani untuk bertanya hal-hal yang belum dipahami, masih kurang paham terhadap materi yang diajarkan dan rendahnya siswa yang mampu menyimpulkan pembelajaran tersebut. Dengan demikian, untuk siklus II hasil belajar siswa mencapai $82,86 \%$. Angka tersebut masih tergolong kriteria baik dalam hal ketuntasan secara klasikal. Oleh karena itu, peneliti harus melakukan siklus III untuk memperbaiki kekurangankekurangan diatas serta untuk meningkatkan hasil belajar siswa dan meningkatkan ketuntasan belajar siswa secara klasikal.

\section{Deskripsi Siklus III}

Siklus II terdiri dari tahap perencanaan, tahap implementasi, tahap observasi dan tahap refleksi. Guru memberikan soal post test kepada siswa setelah proses belajar 
mengajar berlangsung, dengan tujuan untuk mengetahui kemampuan siswa setelah diaplikasikan model Visualize-tion Auditory Kinesthetic (VAK) yang diikuti oleh 34 siswa. Hasil belajar siswa pada siklus III dengan tema 6 subtema 2 dan pembelajaran dapat dilihat pada tabel dibawah ini:

Tabel Pencapaian Hasil Belajar Tematik Siswa pada Siklus III

\begin{tabular}{|c|c|c|c|c|c|}
\hline No & Nama Peserta Didik & KKM & Nilai & Tuntas. & Belum Tuntas. \\
\hline 1 & Adnan Pikri Arrahman & 80 & 80 & $\sqrt{3}$ & \\
\hline 2 & Ahmad Paisal & 80 & 100 & $\checkmark$ & \\
\hline 3 & Amira Puti Maharani & so & 100 & $\checkmark$ & \\
\hline 4 & Angelita Felia Annisa & 80 & 80 & $\checkmark$ & \\
\hline 5 & Aqil Okta Fitma. & 80 & 60 & & $\sqrt{ }$ \\
\hline 6 & Aqilah Fatixah Adzka & 80 & 100 & $\checkmark$ & \\
\hline 7 & Aulia Fitri & 80 & 80 & $\checkmark$ & \\
\hline 8 & Rauziab In Aroila & 80 & 100 & $\checkmark$ & \\
\hline 9 & Haykal Azmi & 80 & 80 & $\checkmark$ & \\
\hline 10 & Torahim Arrasyid. Idri & 8O & 80 & $\checkmark$ & \\
\hline 11 & Kevin Trio Putra & 80 & 80 & $\checkmark$ & \\
\hline 12 & Kirana Zazkia Putriayu & so & 100 & $\checkmark$ & \\
\hline 13 & Mirtahul Rahmi & 80 & 80 & $\checkmark$ & \\
\hline 14 & Muhammad Fajri & 80 & 100 & $\checkmark$ & \\
\hline 15 & Muhammad Parel Alrazag. & so & 100 & $\checkmark$ & \\
\hline 16 & Muhammad Fathir. & 80 & 80 & $\sqrt{ }$ & \\
\hline 17 & Muhammad Ikhaan & 80 & 80 & 2 & \\
\hline 18 & Muhammad Rizki & 80 & 80 & $\sqrt{ }$ & \\
\hline 19 & Muhammed Faiz Hafidzi & 80 & 100 & 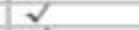 & \\
\hline 20 & Nadia Ramadhani & 80 & 100 & $\sqrt{ }$ & \\
\hline 21 & Nadifa. Nur Axizah & so & 100 & $\checkmark$ & \\
\hline 22 & Nazwa Lailatul Wahda. & 80 & 80 & $\sqrt{ }$ & \\
\hline 23 & Okta Dava Saputra & 80 & 80 & $\sqrt{ }$ & \\
\hline 24 & Pathul Ma:Arii & so & 100 & $\checkmark$ & \\
\hline 25 & Rakha Alvaro Danendra. & 80 & 80 & $\checkmark$ & \\
\hline 26 & Redyna Desvita & 80 & 100 & 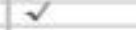 & \\
\hline 27 & Rehan Setiawan & 80 & 40 & & $\checkmark$ \\
\hline 28 & Rifatul Aisyah. & 80 & 80 & $\checkmark$ & \\
\hline 20 & Risky Alfathah & 80 & 100 & $\sqrt{ }$ & \\
\hline 30 & Stcyi Fadilla & so & 100 & $\sqrt{2}$ & \\
\hline 31 & Syiqqisl Arafat Furganiy. & 80 & 80 & $\checkmark$ & \\
\hline 32 & Uswatur Rijal & so & 60 & & $\checkmark$ \\
\hline 33 & Valiza Roon & 80 & 80 & $\sqrt{ }$ & \\
\hline 34 & Dwi Meylantia Saputri & so & 100 & $\checkmark$ & \\
\hline \multicolumn{3}{|c|}{ Jumlah } & 2940 & 31 & 3 \\
\hline \multicolumn{3}{|c|}{ Nilai rata - rata siswa } & 86,47 & & \\
\hline \multicolumn{4}{|c|}{ Fscrentass. Ketrotasio. } & $91.18 \%$ & $8,82 \%$ \\
\hline
\end{tabular}

Berdasarkan daftar nilai hasil belajar siswa pada tabel dapat diketahui bahwa jumlah siswa yang tuntas belajar sebanyak 31 orang dengan persentase $91,18 \%$ sedangkan siswa yang tidak tuntas belajar sebanyak 3 orang dengan persentase $8,82 \%$. Dengan demikian ketuntasan siswa secara klasikal 91,43\% sudah tergolong kriteria baik sekali dan ketuntasan siswa pada siklus III sudah berhasil dan hasil belajar siswa setiap mengalami peningkatan dari siklus sebelumnya ke siklus selanjutnya. Pencapaian hasil belajar siswa pada siklus II disajikan dalam bentuk diagram tabung sebagai berikut:

\section{Gambar Pencapaian Hasil Belajar Siswa pada Siklus III}

Tabel di atas menunjukkan bahwa hasil belajar siswa masih ada 3 orang yang tidak tuntas belajarnya. Namun, selama kegiatan pembelajaran berlangsung siswa semakin aktif, hal tersebut dapat dilihat pada tabel observasi aktivitas siswa yang setiap siklusnya mengalami peningkatan. Berdasarkan hasil pengamatan semua siklus pembelajaran, maka dapat disimpulkan bahwa penggunaan model Visualize-tion Auditory Kinesthetic (VAK) dapat meningkatkan hasil belajar dan ketuntasan secara klasikal sudah tercapai serta model Visualize-tion Auditory Kinesthetic (VAK) ini juga memenuhi kebutuhan siswa dalam belajar yang masing-masing siswa itu berbeda-beda modalitas belajarnya tapi disatukan dalam sebuah model yang menyatukan ketiga modalitas belajar siswa, sehingga modalitas tersebut dirasakan oleh siswa secara keseluruhan selama proses pembelajaran berlangsung. Ketuntasan semua siklus dalam belajar secara klasikal dapat dilihat pada tabel di bawah ini: 
Tabel Ketuntasan Hasil Belajar

\begin{tabular}{|c|c|c|c|c|c|c|c|}
\hline \multirow[b]{2}{*}{ No } & \multirow[b]{2}{*}{ Ketuntasan } & \multicolumn{3}{|c|}{ Frekuensi (F) } & \multicolumn{3}{|c|}{ Persentase (\%) } \\
\hline & & $\begin{array}{l}\text { Siklus } \\
\text { I }\end{array}$ & $\begin{array}{l}\text { Siklus } \\
\text { II }\end{array}$ & $\begin{array}{l}\text { Siklus } \\
\text { III }\end{array}$ & Siklus & $\begin{array}{l}\text { Siklus } \\
\text { II }\end{array}$ & $\begin{array}{l}\text { Siklus } \\
\text { III }\end{array}$ \\
\hline 1 & Tuntas, & 23 & 27 & 31 & $67,65 \%$ & $79,41 \%$ & $91,18 \%$ \\
\hline 2 & Tidak & 11 & 7 & 3 & $32,35 \%$ & $20,59 \%$ & $8,82 \%$ \\
\hline \multicolumn{2}{|c|}{ Jumlah } & 34 & 34 & 34 & $100 \%$ & $100 \%$ & $100 \%$ \\
\hline
\end{tabular}

Berdasarkan tabel di atas, ketuntasan belajar siswa secara klasikal pada kelas V-A UPT. SD Negeri 01 Limo Kaum dengan menggunakan model Visualization Auditory Kinestetic dapat disimpulkan bahwa hasil ketuntasan belajar siswa secara klasikal tercapai pada siklus III. Pencapaian ketuntasan hasil belajar siswa selama penelitian disajikan dalam bentuk diagram tabung sebagai berikut

\section{Gambar Pencapaian Ketuntasan Hasil Belajar Siswa Pembahasan}

Proses pembelajaran dapat dikatakan optimal apabila terdapat keaktifan siswa dan guru dalam proses pembelajaran yang nantinya berdampak pada peningkatan hasil belajar siswa sehingga proses pembelajaran dapat berkualitas, baik dari segi kognitif maupun afektif. Tercapainya suatu tujuan pembelajaran dapat dikatakan bahwa guru telah berhasil dalam mengajar. Keberhasilan kegiatan belajar mengajar diketahui setelah diadakan tes dengan seperangkat soal. Sejauh mana tingkat keberhasilan kegiatan belajar mengajar dapat dilihat dari daya serap anak didik dan persentase keberhasilan anak didik dalam mencapai tujuan pembelajaran dapat diketahui melalui hasil belajar siswa. Berikut ini penulis akan membahas tentang hasil belajar siswa dan analisis data terhadap aktivitas guru dan siswa terhadap penggunaan model Visualization Auditory Kinestetic pada tema Panas dan Perpindahannya.

Untuk memperoleh data dalam penelitian ini penulis tidak hanya bekerja sendiri, akan tetapi adanya guru pengamat untuk mengamati aktivitas guru dan siswa selama proses belajar mengajar. Dari hasil analisis aktivitas guru selama tiga siklus mengalami peningkatan. Hal ini dapat dilihat dari skor rata-rata yang di peroleh pada siklus I sebesar 71,88\% kategori baik, siklus II sebesar 76,56\% kategori baik, dan siklus III sebesar $95,31 \%$ dan dikategorikan sangat baik. Untuk lebih jelas lihat diagram tabung berikut :

\section{Gambar Persentase Aktivitas guru}

Data tersebut menunjukkan bahwa aktivitas guru dalam penggunaan model Visualization Auditory Kinestetic (VAK) termasuk kategori baik. Aktivitas guru dalam melaksanakan pendekatan penggunaan model Visualization Auditory Kinestetic (VAK) pada kegiatan awal, inti, dan akhir sudah terlaksana sesuai dengan rencana yang disusun pada RPP dan mencerminkan model Visualization Auditory Kinestetic (VAK).

\section{Aktivitas Siswa}

Hasil analisis data aktivitas siswa selama penggunaan model Visualization Auditory Kinestetic (VAK) selama tiga siklus adalah siklus I diperoleh nilai persentase sebesar $70,31 \%$ termasuk kategori Cukup, siklus II diperoleh nilai persentase sebesar 75\% termasuk kategori baik, dan siklus III diperoleh nilai 
persentase sebesar $87,5 \%$ termasuk kategori sangat baik. Berdasarkan hasil analisis data terlihat adanya peningkatan pada aktivitas siswa dengan penggunaan model Visualization Auditory Kinestetic (VAK). Untuk lebih jelas lihat diagram tabung berikut :

\section{Gambar Persentase Aktivitas guru}

Meningkatnya aktivitas guru berpengaruh terhadap aktivitas siswa dan hasil belajar siswa, sehingga menunjukkan pembelajaran tersebut bermakna bagi siswa. Salah satu pembelajaran bermakna adalah dengan melibatkan siswa secara aktif dan kreatif dalam mengembangkan daya imajinasinya untuk berpikir. Hal ini sesuai dengan model Visualization Auditory Kinestetic (VAK) yang melibatkan siswa aktif dalam proses belajar untuk menemukan pembelajaran yang bermakna.

\section{Hasil Belajar Siswa.}

Siswa dikatakan tuntas belajar apabila hasil belajarnya memenuhi Kriteria Ketuntasan Minimal (KKM) 80 secara individu. Sedangkan ketuntasan secara klasikal apabila jumlah siswa $85 \%$ yang tuntas belajar. Peneliti memperoleh data hasil belajar siswa melalui pemberian tes yang menunjukkan bahwa hasil belajar siswa kelas V-A UPT. SD Negeri 01 Limo Kaum pada siklus I diperoleh nilai rata-rata sebesar 72,94 dengan jumlah siswa yang tuntas 23 orang $(67,65 \%)$ dan siswa yang tidak tuntas sebanyak 11 siswa $(32,35 \%)$. Pada siklus II nilai rata-rata mengalami peningkatan yaitu 75,88 dengan jumlah siswa yang tuntas sebanyak 27 siswa atau sekitar $(79,41 \%)$ dan siswa yang tidak tuntas sebanyak 7 orang $(20,59 \%)$. Pada siklus III nilai rata-ratanya mengalami peningkatan lagi yaitu dengan persentase 86,47 dengan jumlah siswa yang tuntas sebanyak 31 orang $(91,18 \%)$ dan siswa yang tidak tuntas sebanyak 3 orang $(8,82 \%)$. Hasil tes siklus I, siklus II, siklus III, dan tes akhir tersebut menunjukkan bahwa penggunaan model Visualization Auditory Kinestetic (VAK) dapat menuntaskan hasil belajar siswa dan meningkatkan hasil belajar siswa pada tema 6 subtema 2 pembelajaran 2 pada siswa kelas V-A UPT. SD Negeri 01 Limo Kaum Kecamatan Lima Kaum Kabupaten Tanah Datar.

\section{Penutup}

Berdasarkan analisis hasil penelitian yang dilakukan di kelas V-A UPT. SD Negeri 01 Limo Kaum dengan jumlah siswa 34 orang. Maka dapat diambil kesimpulan sebagai berikut: 1) Aktivitas guru dalam mengelola pembelajaran dapat dilihat guru mampu mengelola pembelajaran dengan baik. Aktivitas guru dengan menggunakan model Visualization Auditory Kinestetic (VAK dapat dilihat pada siklus I yaitu mencapai $71,88 \%$, dan meningkat pada siklus II mencapai $76,56 \%$ dan meningkat lagi pada siklus III mencapai $95,31 \%$ yang dapat dikategorikan baik sekali; 2) Aktivitas siswa pada saat proses pembelajaran berlangsung setiap siklusnya mengalami peningkatan. Pada siklus I mencapai $70,31 \%$ dan mengalami peningkatan pada siklus II mencapai $75 \%$ dan meningkat lagi pada siklus III mencapai 87,5\% yang dapat dikategorikan baik sekali; 3) Berdasarkan hasil belajar siswa dengan menggunakan model Visualization Auditory Kinestetic (VAK di ke la s V-A UPT. SD Negeri 01 Limo Kaum pada siklus I terlihat bahwa rata-rata ketuntasan $67,65 \%$, yang dapat dikategorikan cukup. Pada siklus II persentase ketuntasan $79,41 \%$. Pada siklus III persentase ketuntasan 91,18\%. 


\section{Daftar Pustaka}

Agus Krisno Budiyanto, Moch. (2016). Sintaks 45 Metode Pembelajaran dalam Student Centered Learning (SCL). Malang: UMM Press.

Arikunto, Suharsimi. (2013). Dasar-dasar evaluasi pendidikan. Jakarta: Bumi Aksara.

DePorter, Bobbi., Mark Reardorn dan Sarah Singer-Nourie. (2011). Quantum Teaching: Mempraktikkan QuanrumLearning di Ruang-ruang Kelas (terj. Ary Nilandari). Bandung: Kaifa.

Daryanto. (2017). Pembelajaran Abad 21. Yogyakarta: Gava Media.

Kadir, Abd. dan Hanun Asrohah. (2014). Pembelajaran Tematik. Jakarta: Rajawali Pers.

Kunandar. (2009). Guru Profesional Implementasi Kurikulum Tingkat Satuan Pendidikan (KTSP) dan Sukses dalam Sertifikasi Guru. Jakarta: Rajawali Pers.

Sanjaya, Wina. (2012). Penelitian Tindakan Kelas. Jakarta: Kencana Prenada Media Group

Siregar, Eveline dan Hartini Nara. (2010). Teori Belajar dan Pembelajaran.Bogor:Ghalia Indonesia.

Sudirman dan Rosmini Maru. (2016). Implementasi Model-Model Pembelajaran dalam Bingkai Penelitian Tindakan Kelas. Makassar: Universitas Negeri Makassar.

Suprihatiningrum, Jamil. (2017). Strategi Pembelajaran: Teori \& Aplikasi, Cet. II. Jogjakarta: Ar Ruzz Media.

Wijaya, Candra dan Syahrum. (2013). Penelitian Tindakan Kelas Melejitkan Kemampuan Peneliti untuk Meningkatkan Kualitas Pembelajaran Guru. Bandung: citapustaka Media Perintis.

Wiyani, Novan Ardy. (2017). Desain Pembelajaran Pendidikan: Tata Rancang Pembelajaran Menuju Pencapaian Kompetensi. Yogyakarta: Ar-Ruzz Media 